
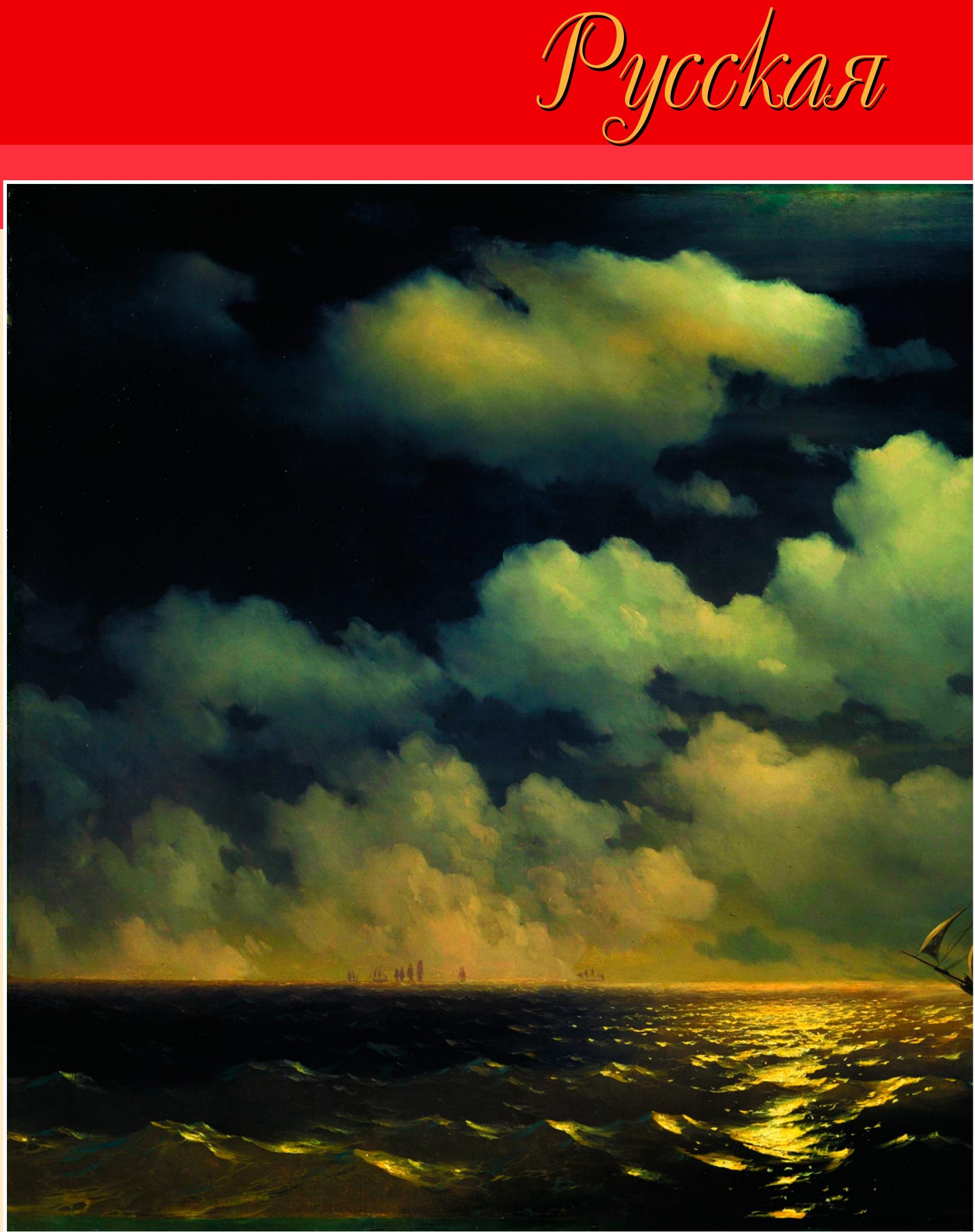

Военный бриг Черноморского флота «Меркурий» после победы над двумя турецкими судами встречается с русской эскадрой. Худ. Иван Константинович Айвазовский. 1848 г.

Государственный Русский музей, Санкт-Петербург. 


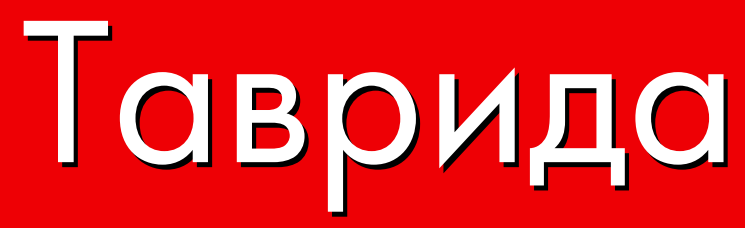

Антон Васильев

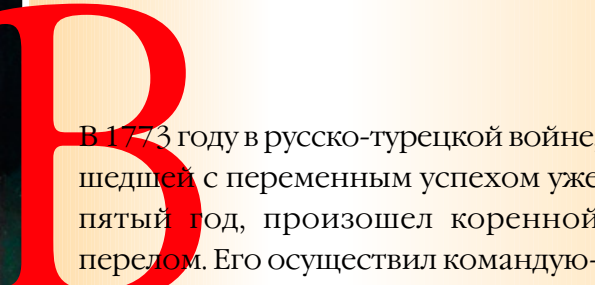

пере, ом. Его осуществил командую-

рал Петр Александрович Румянцев, который, по мнению военного историка Д.Ф. Масловского, был, после Петра Великого, «самый видный деятель в истории военного искусства России, не имеющии себе равного и до позднейшего времени». 18 июня 20-тысячная армия Румянцева осадила крепость Силистрию, гарнизон которой был на 10 тысяч человек многочисленнее осаждавших.

На выручку крепости двинулось еще 30 тысяч турок под командованием Нуман-паши, что грозило Румянцеву ударом с тыла. Навстречу Нуман-паше выступил 5-тысячный корпус генерал-майора Вейсмана. 22 июня 1773 года близ местечка Кайнарджа Вейсман решительно атаковал основные силы Нуманпаши. В начале сражения он встал в первом ряду и личным примером увлек солдат в атаку. Во время боя генерал был убит пулей в сердце. Последние его слова были: «Не говорите людям». Турки не выдержали русского натиска и отступили, потеряв до 5 тысяч человек. Потери 


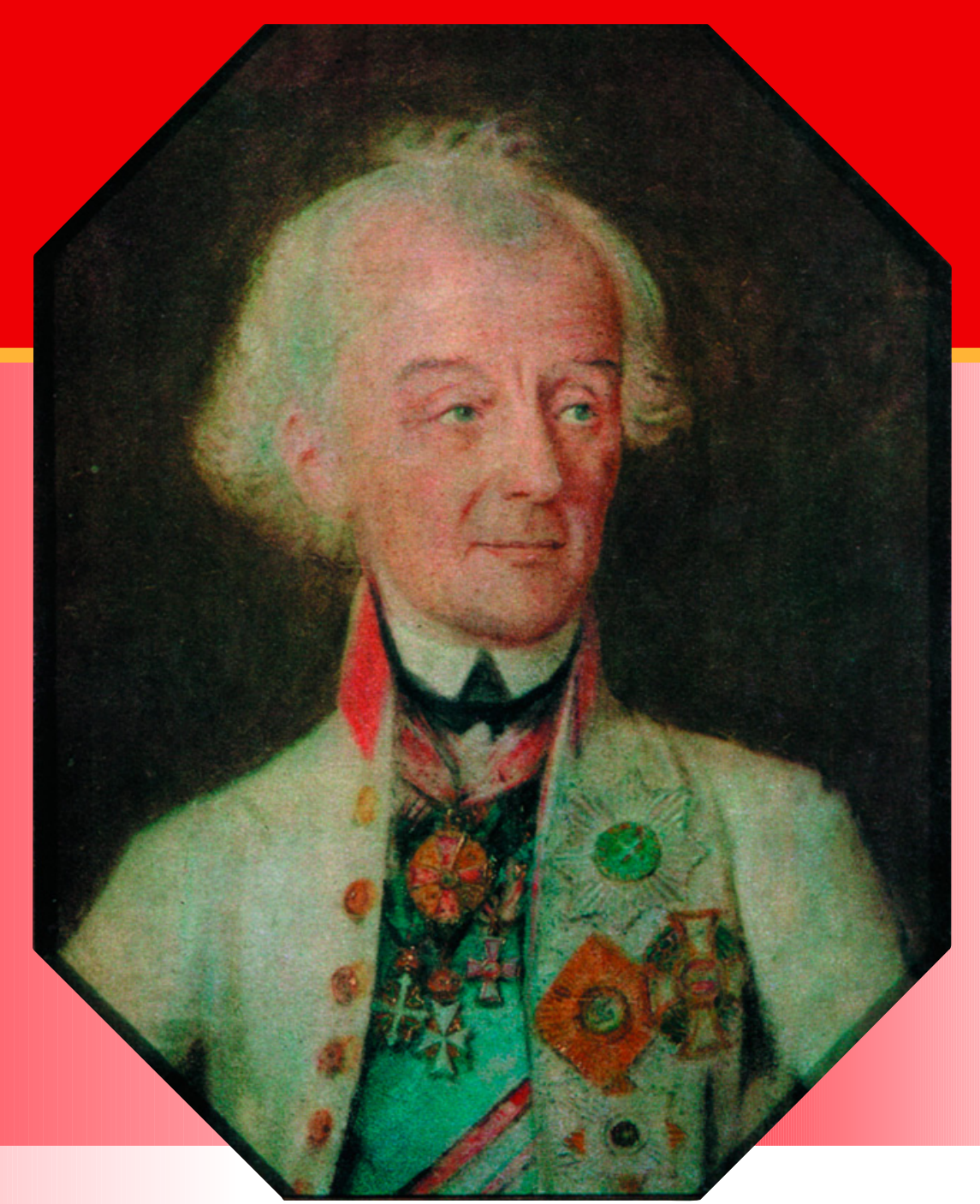

русских составили 167 солдат, но среди них был и их командующий.

На следующий день на Черном море близ Балаклавы два российских корабля «Корона» и «Таганрог» вступили в бой с четырьмя турецки-
Последний прижизненный портрет Александра Васильевича Суворова, написанный с натуры за четыре месяца до смерти полководца.

Худ. Иоганн Генрих Шмидт 1800 г.

Эрмитаж, Санкт-Петербург.
Новороссийска, русская эскадра из 6 кораблей под командованием капитана 2-го ранга голландца Кинсбергена выиграла двухчасовой бой с 18 турецкими кораблями, везшими в Крым шеститысячный десант.

России было невероятно трудно вести войну. Фактически, она воевала на два фронта: в тылу было восстание Пугачева, громившее целые приуральские области. В Турции пришел к власти новый султан, Абдул Хамид I, и турецкая армия воспряла: считалось, что предыдущий правитель, Мустафа, фатально несчастлив и приносит одни поражения. Дипломатия почти не работала: турецкие предложения были для России унизительны, а ответные ноты несли в себе оттенок компромиссов, что для заносчивых османов выглядело, как признак слабости. Оставалось уповать на военный талант российских генералов. С ними Екатерине повезло.

9 июня 1774 года близ болгарского села Козлуджа корпуса Суворова и Каменского вступили в бой с войском турецкого генерала Абдул-Резака. Возглавив атаку кавалерии, Суворов захватил высоту в тылу турецкого лагеря, а затем при поддержке пехоты корпуса Каменского разгромил все войско Абдул-Резака. Урон русских составил 209 человек, турки же потеряли 1200 солдат и офицеров. Победа при Козлудже решила участь кампании 1774 года. После битвы Суворов и Каменский блокировали крепость Шумлу, где находилась ставка великого визиря. Тот уже не имел достаточных сил для продолжения войны.

10-го (21-го по новому стилю) июля 1774 года Румянцев заключил с турками мирный договор вблизи местечка Кючук-Кайнарджи. По ре- 
Генерал-фельдмаршал Петр Александрович Румянцев-Задунайский.

С началом турецкой войны, был назначен командуюоиим второй армией,

охранявшей русские гранищы от набегов крымских татар. Победа, одержанная ии 1 августа 1770 года над вдесятеро сильнейиии неприятелеи при Кагуле, вознесла Румянцева в ряд первых полководцев ХИІІ века.

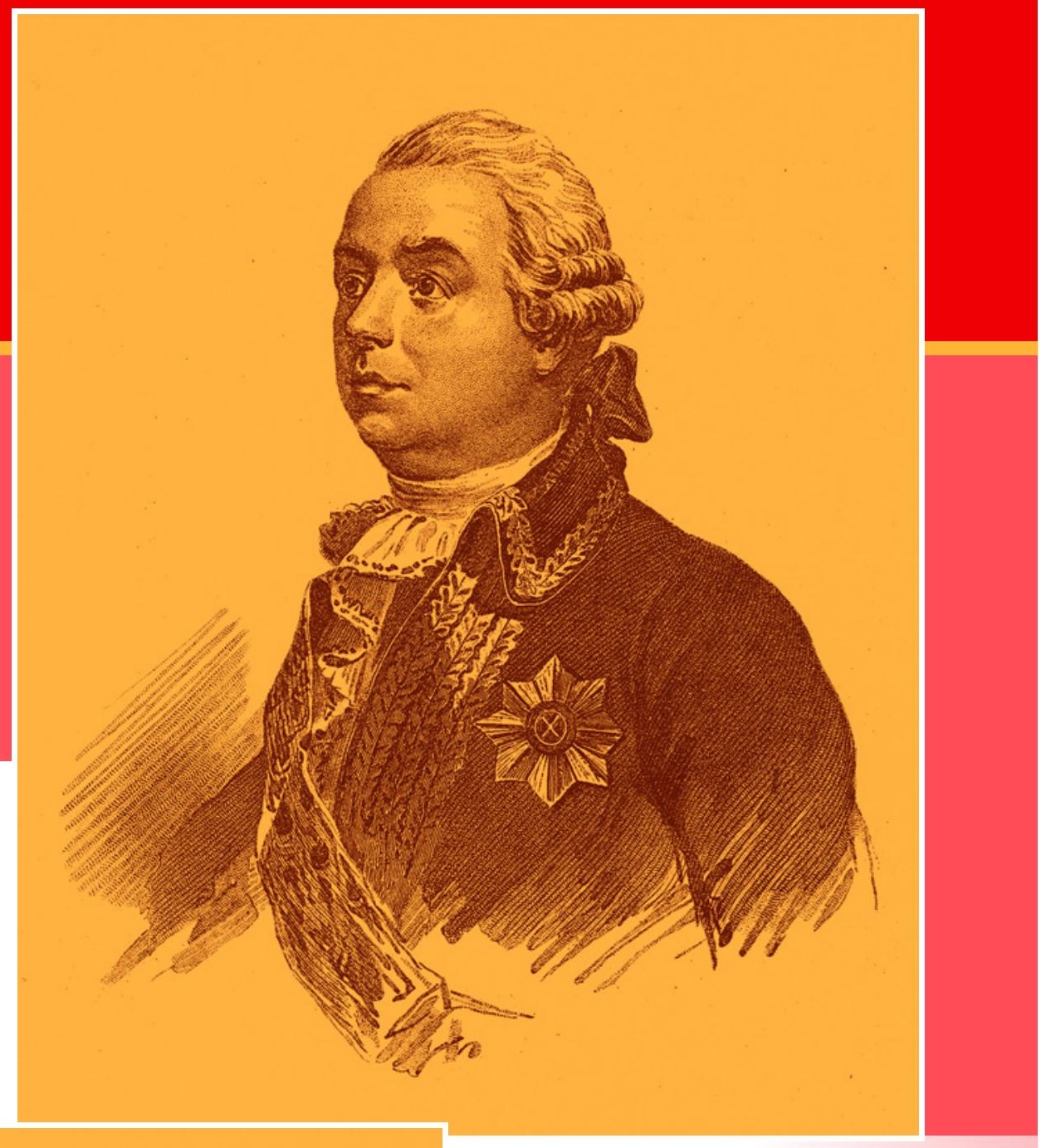

зультатам этого мирного договора Россия получала крепость Кабарда на Кавказе, а также крепости Керчь и Еникале, которые располагались на берегу Керченского пролива в Крыму. Кроме того, Османская империя передавала в состав России земли между южным Бугом и Днеп-

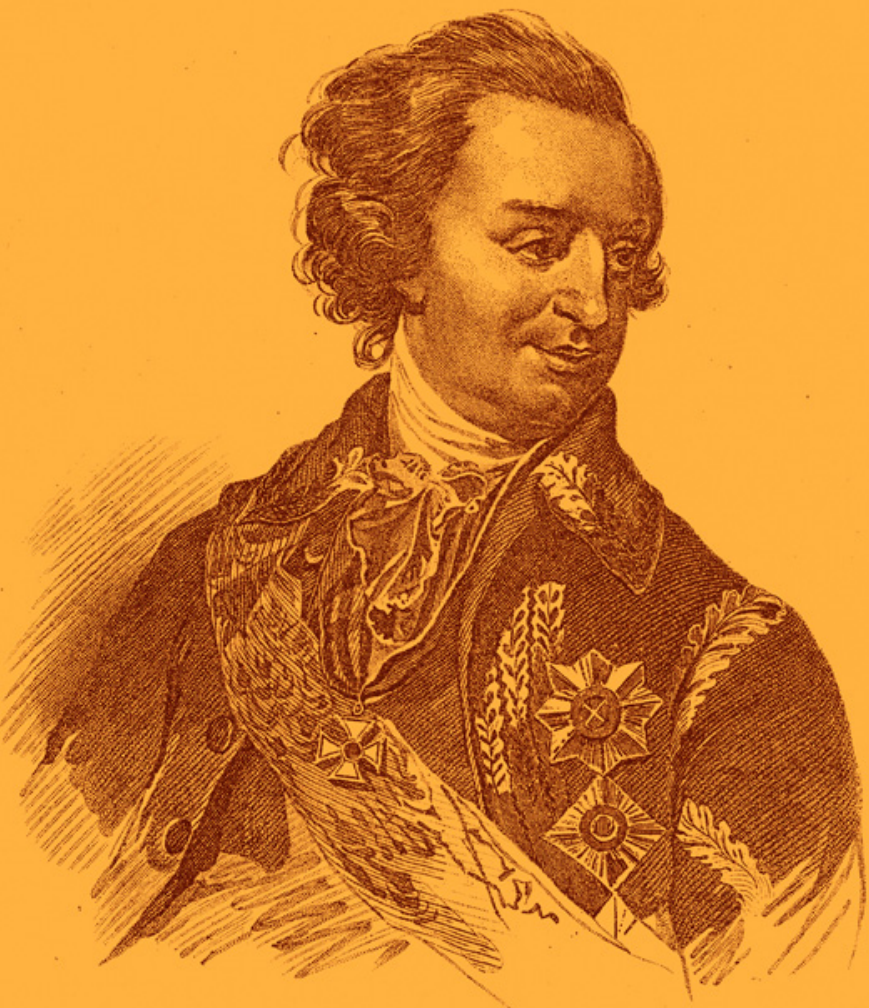

ром. На этом русско-турецкая война 1768-1774 годов была официально окончена.

Разумеется, османы сдались не сразу, русским пришлось сражаться с их десантом в районе Ялты, Кафы и Еникале, а князь Прозоровский разбил 40-тысячное войско турецкого ставленника Девлет-Гирея под Бахчисараем, приведя в Крым русского агента влияния, калгу-султана (наследного принца) Шагин-Гирея к которому весьма благоволила Екатерина, находя его умным и воспитанным человеком.

\section{РОЖДЕНИЕ НОВОРОССИИ}

По Кючук-Кайнарджийскому договору Крымское ханство получило полную «вольность»; но, охваченное российскими крепостями и отрезанное ими и морем от общения с исламским миром, это ханство, естественно, «обрусевало». ШагинГирей возомнил себя реформатором 


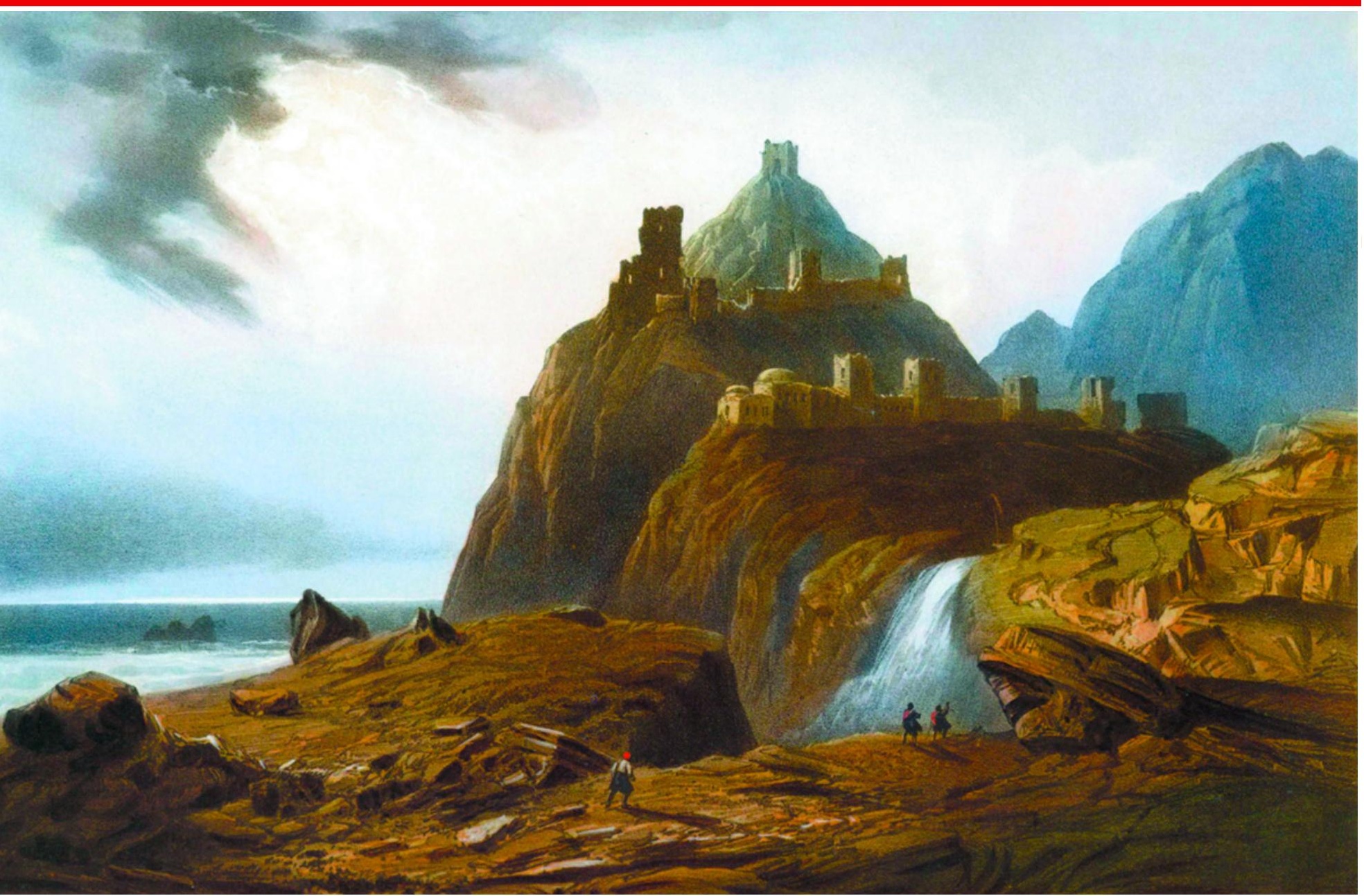

Остатки генуэзской крепости в Судаке. Худ. Карл Боссоли.

Из альбома литографий «Пейзажи и достопримечательности Крыма», издание 1856 г.

в духе Петра Великого, построил пороховой завод в Бахчисарае, уравнял христиан в правах с мусульманами и даже попробовал создать армию по образцу российской (с европейскими мундирами и зуботычинами капралов), к исламу же и обычаям предков относился пренебрежительно.

Прошло несколько лет, и российская власть начала доминировать в крае. Реформы Шагин-Гирея вызывали у татар величайшее озлобление Объявив его шайтаном, продавшимся урусам, мятежные отряды взяли Бахчисарай, ограбив дворец и дома приверженцев хана. В разгоревшейся междуусобице погибло до 12 тысяч человек.

В Крым уже прибыл турецкий ставленник Селим-Гирей, но его в феврале 1778 года окружил и раз- бил князь Прозоровский. Большую работу по обороне полуострова провел Александр Васильевич Суворов, в те годы - командующий Кубанским корпусом: он распорядился построить в Ахтиярской (будущей Севастопольской) гавани береговые батареи, заставившие стоявшую там турецкую эскадру покинуть крымские берега (с адмиралом, командовавшим эскадрой, Суворов почти дружески переписывался!)

Будущий генералиссимус посылал письма и другим военачальникам Блистательной Порты, убеждая их, что намерен твердо отстаивать Крым от любой внешней угрозы. Ни атаковать российские корабли в Черном море, ни высадить в Крыму десант турки не решились. А ШагинГирей, расхрабрившись, вновь начал репрессии, казня поддержавших мятеж подданных, отбирая имущество, изгоняя из Крыма.

Суворов, беспокоясь за христиан - греков и армян, начал их переселение на северный берег Азовского моря, к Азову и Таганрогу (армяне также основали город Нахичевань в низовьях Дона). В письмах он упоминал Шагин-Гирея: «В отчаянностях его иногда помрачается дух; иногда и не трезв!» Из Крыма были выведены десятки тысяч греков и армян. Христиане были старательными работниками, неплохими купцами, и Крым от этой эмиграции довольно сильно обеднел.

Громадные территории между Днестром и Доном, получили название Новороссии. Генерал-поручик Григорий Потемкин, храбро дравшийся с турками при Фокшанах, Ларге и Кагуле, заслуживший ордена 


\section{Будущий генералиссимус посылал письма} и другим военачальникам Блистательной Порты, убеждая их, что намерен твердо отстаивать Крым от любой внешней угрозы. Ни атаковать российские корабли в Черном море, ни высадить в Крыму десант турки не решились. А Шагин-Гирей, расхрабрившись, вновь начал репрессии.

Св. Георгия и Св. Анны, в 1776 году был назначен генерал-губернатором Новороссийской, Азовской и Астраханской губерний, став управителем всех южнорусских земель от Черного до Каспийского морей.

Он начал с заселения новых земель, обещав каждому поселенцу участок в 26 десятин и освобождение от налогов на срок от 6 до 16 лет.
Формально помещичьим крестьянам запрещалось селиться на юге, но наместник смотрел на нарушения этого запрета сквозь пальцы. Жалобы от помещиков, просивших вернуть им беглых холопов, Потемкин уничтожал. Кроме русских, в Новороссию мигрировали молдаване, греки, болгары - всем находилось место.
Внизу:

Инкерманская долина.

Худ. Карл Боссоли.

Из альбома литографий «Пейзажи и достопримечательности Крыма», издание 1856 г.
Колонистам угрожали набеги крымских татар, которые формально оставались независимы. Россия согласилась на то, чтобы крымские татары признавали духовную власть султана как главы мусульман. Это дало султану возможность оказывать на татар и политическое влияние. К осени 1776 года крымцы, подстрекаемые турецкими агента- 
Весной 1782 г. в Крыму вспыхнуло восстание, вдохновленное Мехмед-Гирей Султаном. Шагин-Гирей бежал в Еникале под защиту русских войск, а Батыр был провозглашен ханом. В нарушение мирного договора, позволяющего Турции контролировать лишь религиозные дела в Крыму, турки нового хана признали. Пришлось снова вводить в Крым войска. ми, разорвали в одностороннем порядке Карасубазарский трактат, по которому Крым был самостоятельным ханством, Россия же получала крепости Керчь и Еникале.

Весной 1782 года в Крыму вспыхнуло восстание, вдохновленное Мехмед-Гирей Султаном, возглавили же его родные братья «пророссийского хана», Арслан и Батыр. ШагинГирей бежал в Еникале под защиту русских войск, а Батыр был провозглашен ханом. В нарушение мирного договора, позволяющего Турции контролировать лишь религиозные дела в Крыму, турки нового хана 


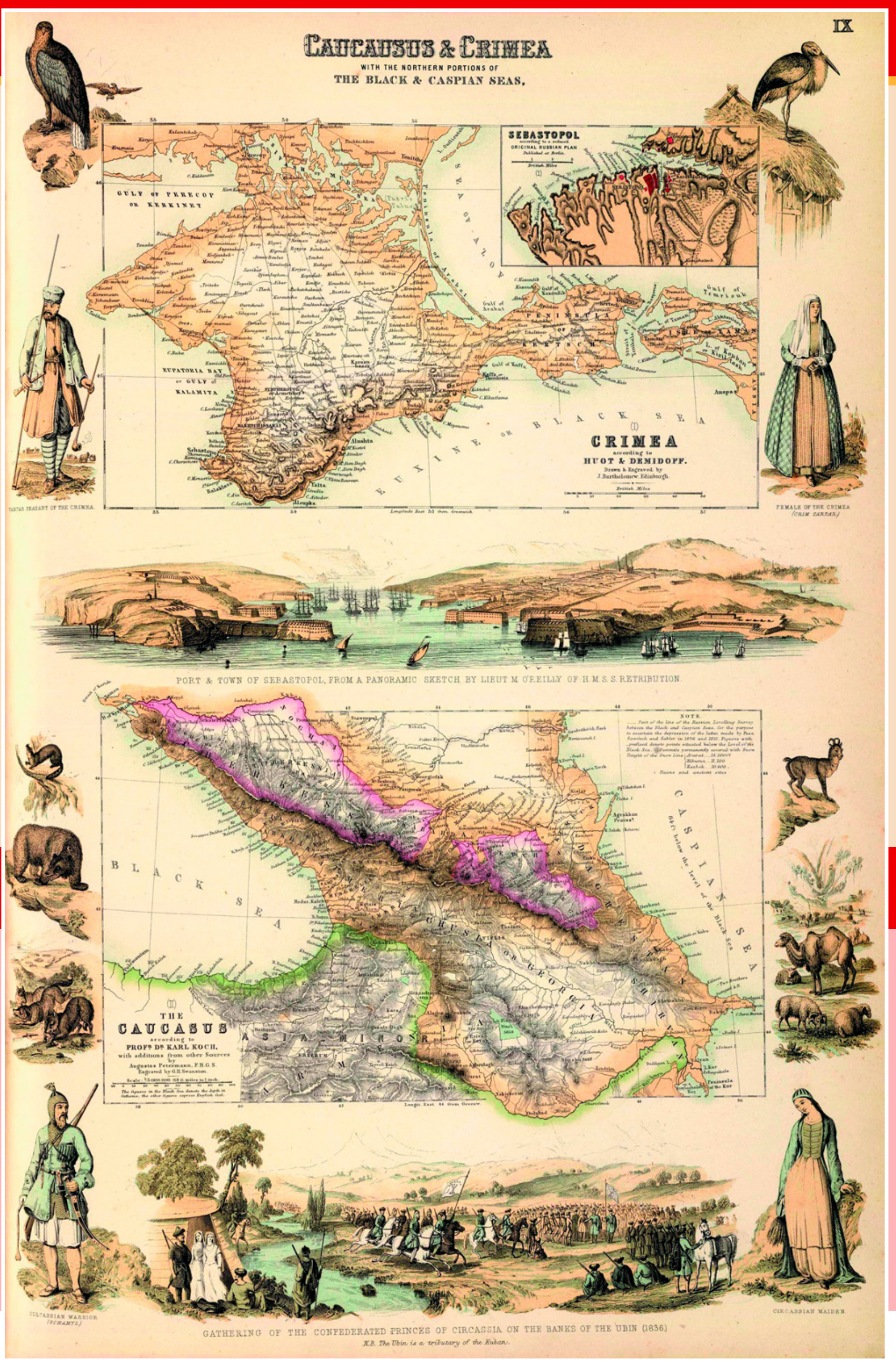




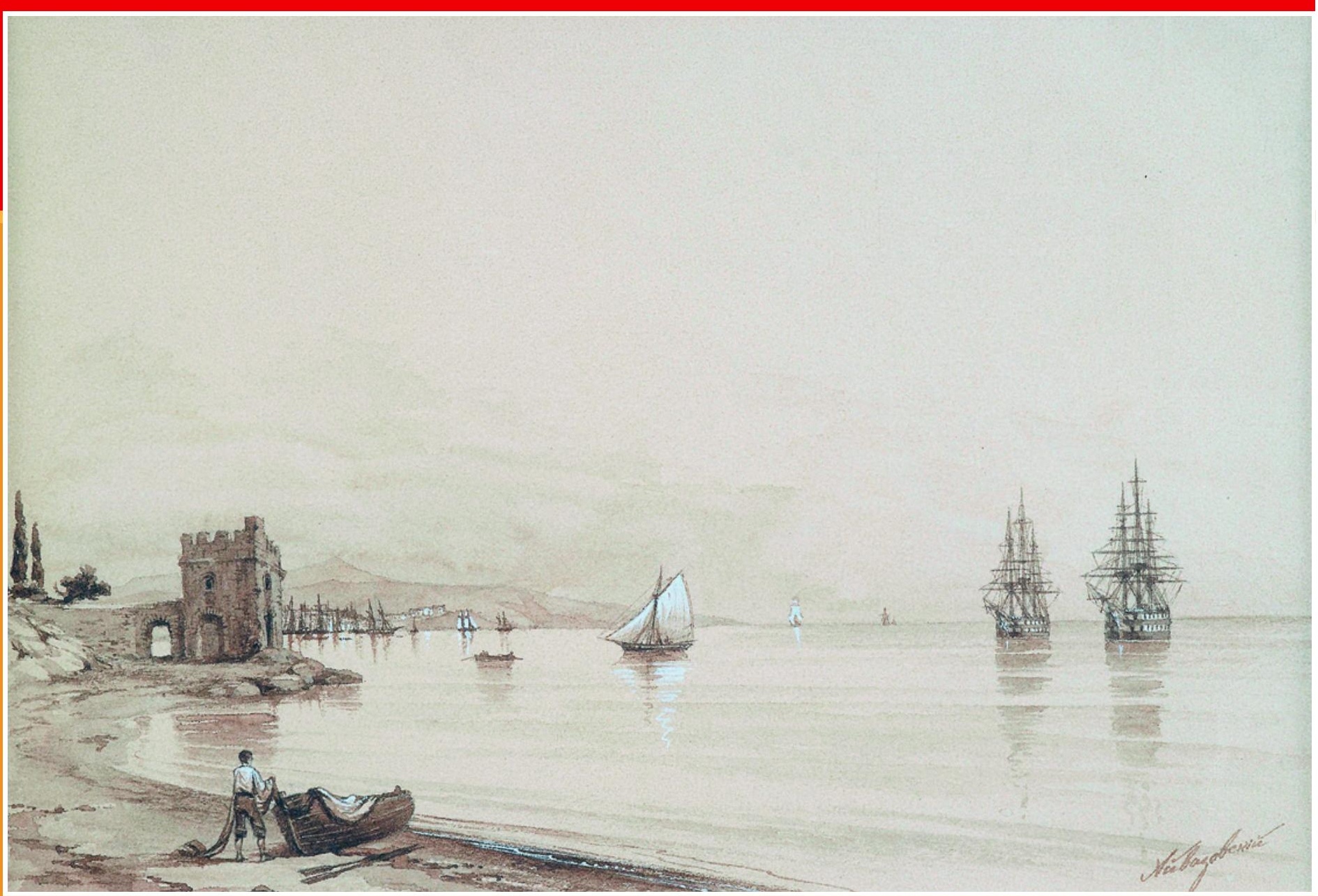

Вид на бухту с парусными судами.

Худ. Иван Константинович Айвазовский. Дата неизвестна.

Галерея аукционного дома Nagel.

\section{О Херсоне императрица писала графу} Брюсу, что «узрели прекрасный город, где шесть лет назад не было ничего, окроме голой земли, притом в лучшем виде», посетила Бахчисарай и Инкерман в Ахтиярской гавани. нуть на месте Ахтияра большую крепость и назвать ее Севастополь в переводе с греческого «Город, достойный поклонения» или «Священный город». А комендантом крепости стал капитан I ранга Федор Федорович Ушаков, составивший весь первоначальный план строительства главной базы. Под его руководством строились жилые дома, госпиталь, склады, был разбит общественный сад - Ушакова балка.

В том же 1784 году светлейший приказал основать столицу Таврической губернии на месте татарской столицы калга-султанов Ак-Мечети, на «брегах веселых Салгира», воспетых Пушкиным в «Бахчисарайском фонтане». Рядом с мечетью КебирДжами, где ранее стояли лагерем войска Суворова и ДолгоруковаКрымского, началось строительство православного храма, жилых и административных зданий. Город, включавший в себя как вновь построенные кварталы, так и территорию Ак-Мечети, получил название Симферополь - в переводе с греческого «город пользы».

В 1787 году Екатерина II предприняла свое знаменитое путешествие в Крым. Потемкин организовал весь маршрут императрицы, которая увидела только что построенные деревни и города. О Херсоне она писала графу Брюсу, что «узрели прекрасный город, где шесть лет назад не было ничего, окроме голой земли, притом в лучшем виде», посетила Бахчисарай и Инкерман в Ахтиярской гавани.

Французский посол граф Л.Ф.де Сегюр напишет по этому поводу в мемуарах: «Проехав залив,мы пристали к подножию горы, на которой полукружием возвышался Севастополь. Несколько зданий для склада товаров, адмиралтейство, городские 


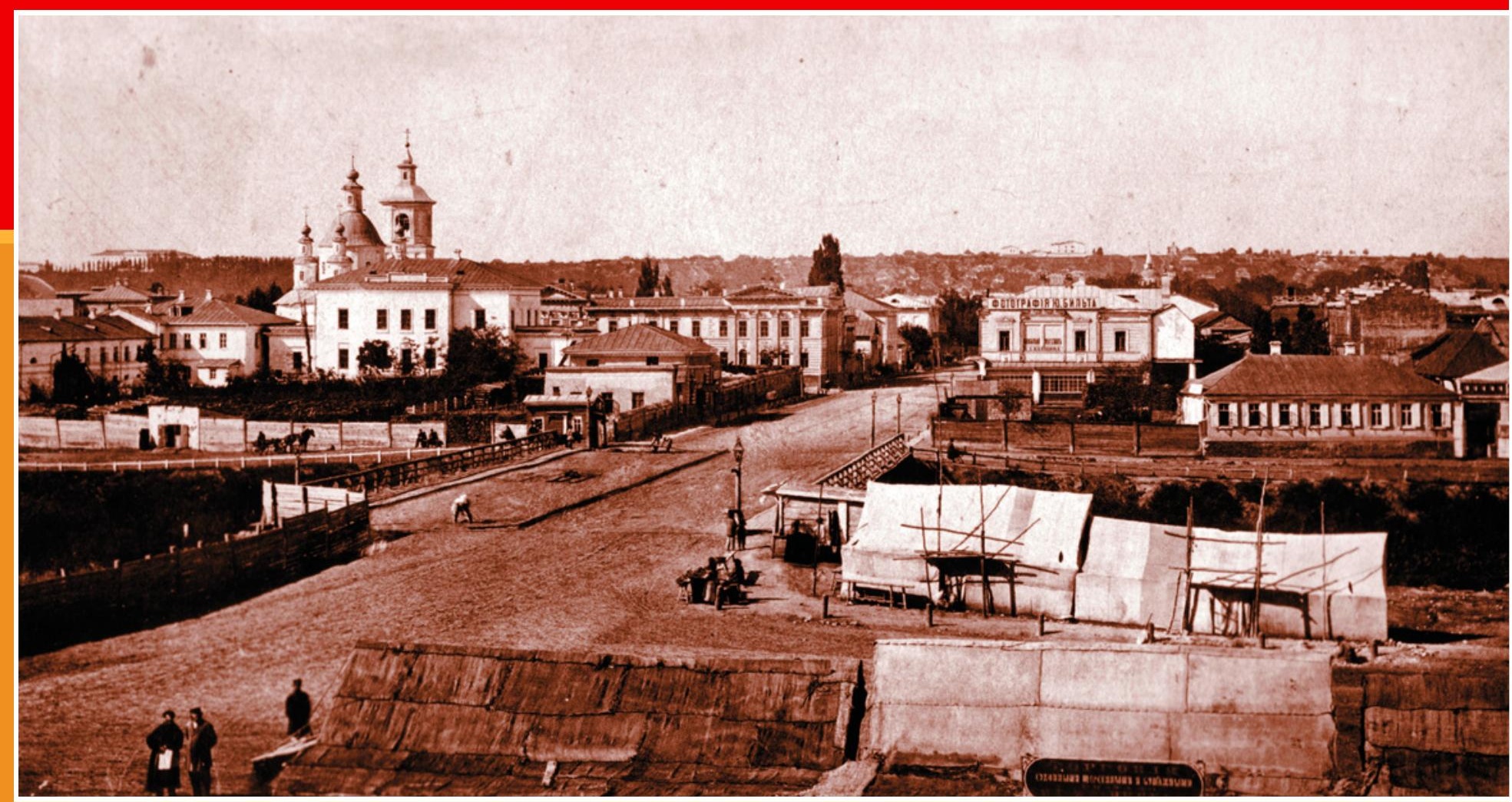

Екатеринославская улица в Харькове.

Вид с Университетской горки.

Фотография сделана известным русским

фотографом Василием Сергеевичем Досекиным в 1879 г.

укрепления, четыреста домов, толпь рабочих, сильный гарнизон, госпиталь, верфи, пристани, торговая и карантинная, все придавало Севастополю вид довольно значительного города. Нам казалось непостижимьи, каким образом в 2000 верстах от столицы, в недавно приобретенном крае, Потемкин нашел возможным воздвигнуть такие здания, соорудить город, создать флот и поселить столько жителей. Это действительно бъл подвиг необыкновенной деятельности! <... Богатства степного края, быстрое развитие

Фейерверк в честь Екатерины II во время ее путешествия в Крым. Худ. Ян Богомил Плерш.
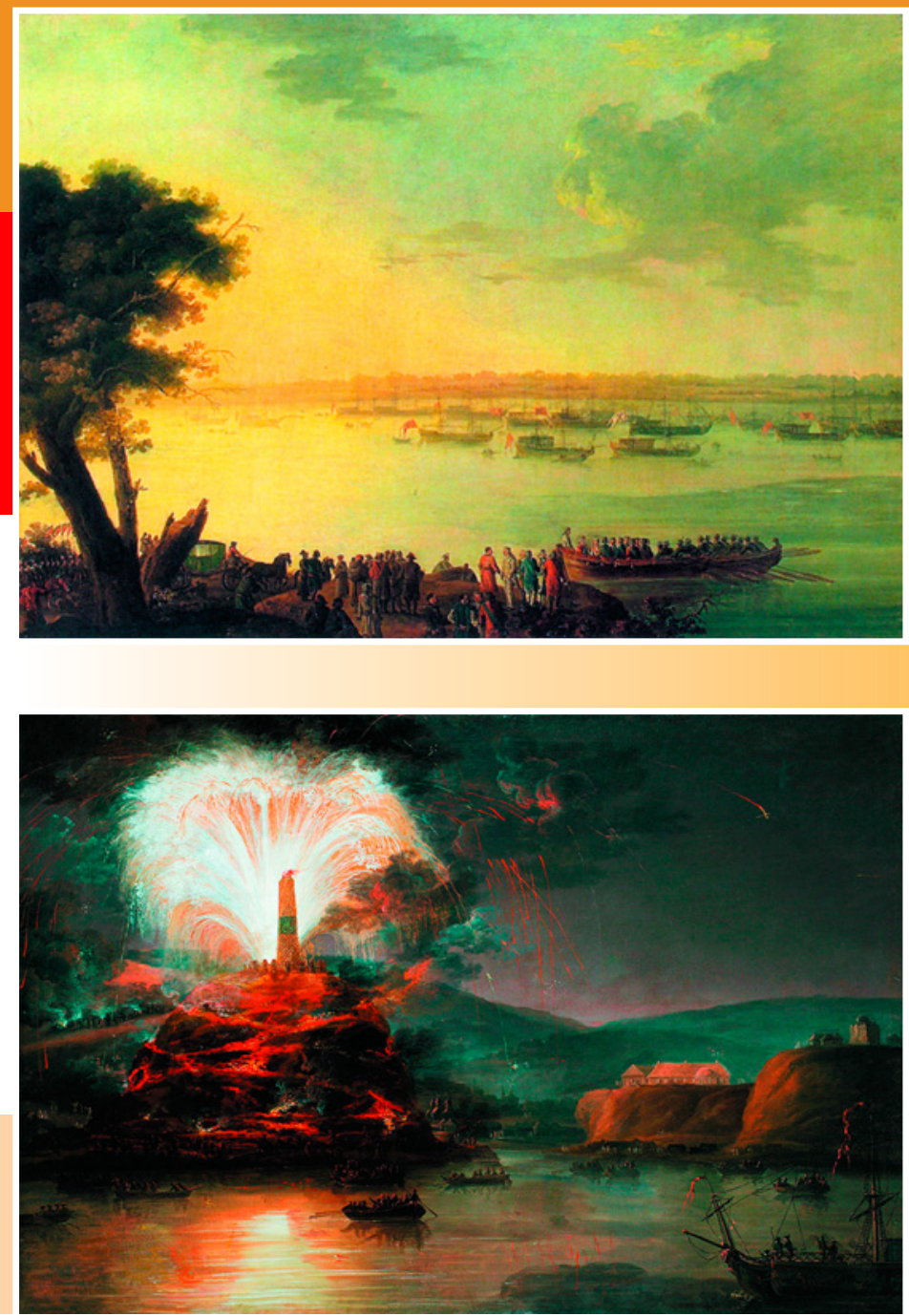
Под руководством Потемкина была заложена верфь в устье реки Ингул, вокруг нее сформировался городок. В декабре 1788 г., в день Николая Угодника (Николы Зимнего) Суворов после долгой осады взял Очаков. В честь этой победы светлейший велел назвать новый город Николаевом.
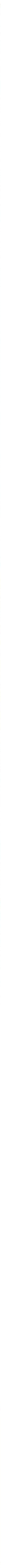

городов, изобилие военных запасов и снарядов, отличное устройство войска, значение военных портов, прелесть южной природы в Крыму, заботливость князя при управлении всем краем, - все это должно было поразить Екатерину, обезоружить недоброжелателей князя и в то же время привести в удивление Европу. На Западе должны были узнать, какими источниками богатства и могущества располагает Россия».

Екатерининская миля в Бахчисарае один из дорожных знаков, построенных в 1784-1787 годах на предполагаемом пути следования императрицы Екатерины Великой в Крым. 
